University of Nebraska - Lincoln

DigitalCommons@University of Nebraska - Lincoln

Biological Systems Engineering: Papers and

Publications

Biological Systems Engineering

2010

\title{
Extrusion Systems: Design
}

Qi Fang

Banner Pharmacaps, Inc., High Point, North Carolina

Milford Hanna

University of Nebraska-Lincoln, mhanna1@unl.edu

Follow this and additional works at: https://digitalcommons.unl.edu/biosysengfacpub

Fang, Qi and Hanna, Milford, "Extrusion Systems: Design" (2010). Biological Systems Engineering: Papers and Publications. 311.

https://digitalcommons.unl.edu/biosysengfacpub/311

This Article is brought to you for free and open access by the Biological Systems Engineering at DigitalCommons@University of Nebraska - Lincoln. It has been accepted for inclusion in Biological Systems Engineering: Papers and Publications by an authorized administrator of DigitalCommons@University of Nebraska Lincoln. 


\title{
Extrusion Systems: Design
}

\author{
Qi Fang \\ Research and Development, Banner Pharmacaps, Inc., High Point, North Carolina, U.S.A.
}

Milford A. Hanna

Biological Systems Engineering Department, Industrial Agricultural Products Center, University of Nebraska-Lincoln, Lincoln, Nebraska, U.S.A.

\begin{abstract}
Extrusion processing is applied widely because of its versatility and the fact that no waste streams, other than some heat, are generated. The versatility is a result of the way extruders are designed, in terms of the way preconditioning and postprocessing operations can be added with ease, and in terms of the wide range of processing conditions that can be generated through the selection of barrel, screw, and die options and operating conditions, such as temperature, screw speed, and feed moisture content.
\end{abstract}

\section{INTRODUCTION}

Extrusion processing has been applied widely by the food industry for manufacturing numerous products such as pasta, ready-to-eat cereal, flat bread, pepperoni, and pet food. Extrusion can be used to perform various types of tasks, including mixing, kneading, dispersing, plasticizing, gelatinizing, texturizing, cooking, melting, roasting, caramelizing, sterilizing, drying, crystallizing, reacting, and shaping.[1] Extrusion technology has advantages over other conventional processing methods such as adaptability, productivity, quality, and energy efficiency. Each food product requires a different setup of the extrusion system to achieve the desired degree of processing. A complete extrusion system generally consists of raw material receiving and storage, mixing, preconditioning, extrusion, drying, and packaging (Figure 1).

\section{RAW MATERIAL RECEIVING AND STORAGE}

Raw materials usually are received in bulk or bags. They are first checked for quality-control purposes and then stored in bins for subsequent use.

\section{MIXING}

Blending of various ingredients can be performed either before extrusion or inside the extruder. Mixing prior to extrusion can be accomplished in a mixer by preblending all dry and liquid ingredients together according to a predetermined formula. In order for moisture to be distributed evenly, the mixed ingredients need to be held for a certain time in a closed container. Ingredients can also be mixed in the preconditioner of the extruder. Liquid ingredients can be injected through ports located in the preconditioner or in the extruder barrel.

\section{EXTRUSION SYSTEM}

Figure 2 shows a single-screw extruder configurations commonly used for food processing. It consists of a preconditoner, a main drive unit, a barrel, one or two screws, and a die. Extruders are typically classified into two categories: singlescrew extruder and twin-screw extruder. Historically, singlescrew extruders have been used extensively in the food industry due to their low cost, simplicity, and robustness. However, twin-screw extruders have gained popularity because of their versatility and other advantages over single-screw extruders.

\section{PRECONDITIONER}

Preconditioning adjusts the moisture content of the feed materials and can be used to precook the feed materials. The incorporation of a preconditioner in the system results in reduced wear to the extruder, lower overall energy usage, and higher extruder throughput. Preconditioners can be classified into single-shaft and double-shaft designs. Doubleshaft preconditioners have gained popularity in recent years for their ability to uniformlymix and effectively transfer heat.

\section{SINGLE-SCREW EXTRUDER}

A single-screw extruder has only one screw rotating within the barrel. The screw can be built in a solid 


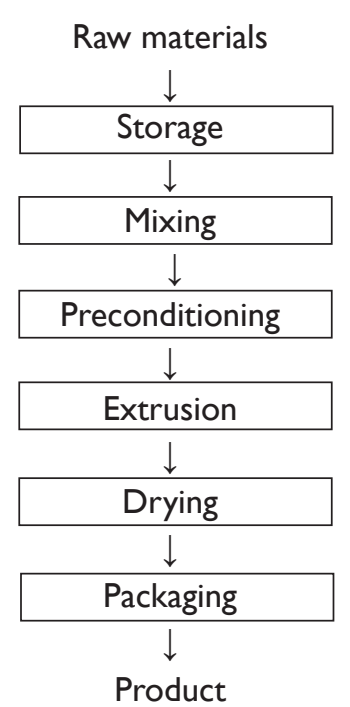

Figure 1. Components of an extruder system.

piece or assembled of screw segments. The latter allows changes in screw configurations. The rotating action of the screw mixes and transports the feed materials from the feeding zone to the die exit. A forward motion takes place with the assistance of raised flights having a helical profile (Figure 3). Similar to the screw, the barrel in which the screw rotates can be manufactured as a single piece (for smaller laboratory extruders) or as segmented sections that are bolted together (for commercial production). A single-screw extruder can be modeled as a drag flow pump. The material within the barrel is transported in the form of a plug. Mixing between the inner layer next to the screw and the outer layer next to the barrel is limited. By adding interrupted flights and kneading blocks, mixing can be accomplished but with a reduced throughput.

Depending on the extent of shearing action, singlescrew extruders can perform low, intermediate, and highshear extrusions. Low-shear extruders with smooth barrels, deep flights, and low screw speeds are used for the production of pastas, meats, cereals, and fried snacks. Moderate-shear extruders, with grooved barrels and highcompression- ratio screws, are used for cooking extrusions, such as bacteria pasteurization, enzyme inactivation, protein denaturation, and starch gelatinization.[2] High-shear extruders, with grooved barrels, variable pitch and flight depth screws, and interrupted screw flights, are used for high-temperature/short-time (HTST) cooking of ready-to-eat cereals, snacks, candies, expanded pet foods, soup mixes, and texturized soy proteins.[3]

\section{TWIN-SCREW EXTRUDER}

Based on the relative positions of the two screws, there are four types of screw configurations available: corotating intermeshing, corotating non-intermeshing, counterrotating intermeshing, and counterrotating non-intermeshing. For food processing, corotating intermeshing twin-screw extruders are the most widely used. This type of twinscrew extruder works as a positive displacement pump to transport materials inside the extruder barrel with the ability to convey materials with very high to very low viscosities, which means a wider

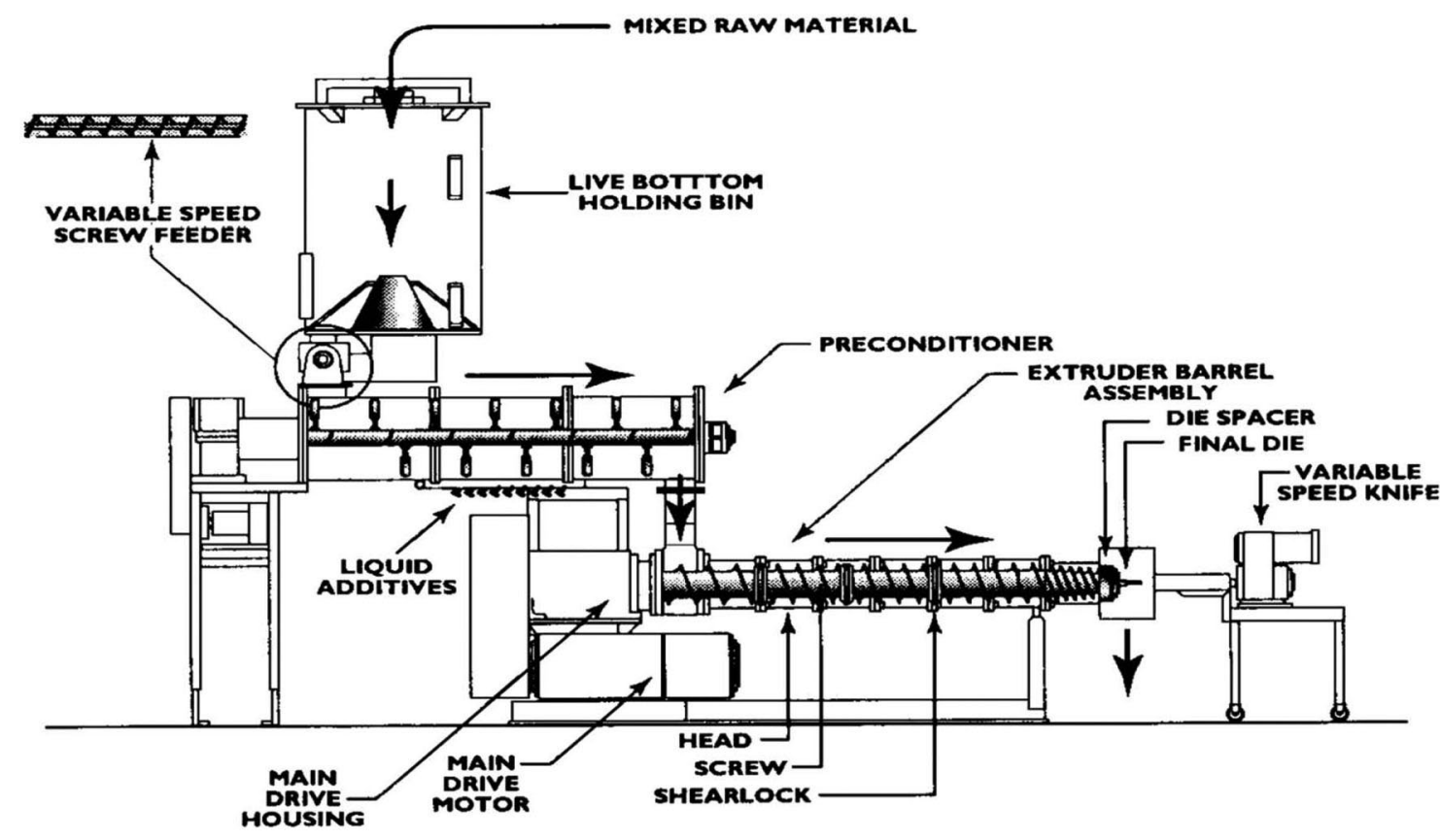

Figure 2. A single-screw extruder. Source: From Single screw extruder, in Extruders in Food Applications.[2] 


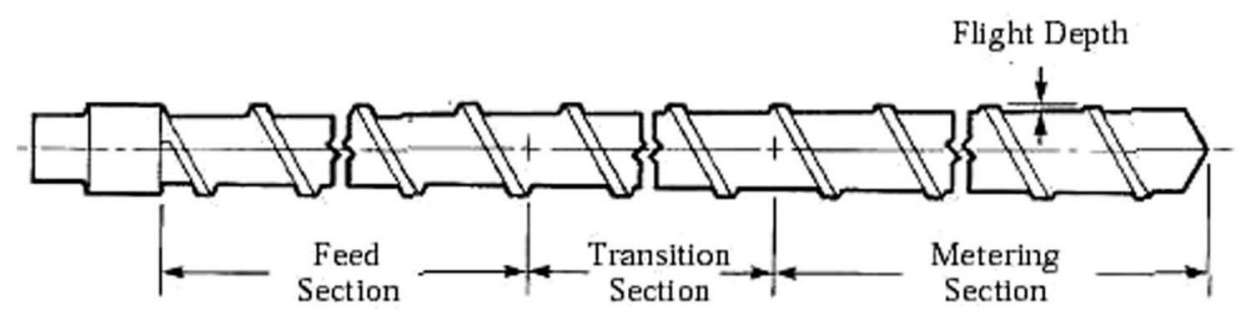

Figure 3. A typical screw configuration.

range of moisture contents is allowed in the raw materials. Other distinct advantages of the twin-screw extruders over the single-screw extruders are the excellent material mixing and heat transfer, which take place mostly at the intermeshing region of the two screws. Efficient mixing and heat transfer are critical for the manufacturing of certain products. Except small-scale machines, most twin-screw extruders have segmented screws and barrels for flexible screw configurations and easy manufacturing. For example, the inclusion of kneading blocks provides excellent mixing action for processing of materials containing ingredients having different characteristics.

\section{FACTORS AFFECTING EXTRUSION}

\section{Feed Moisture Content}

Moisture in the raw materials has multiple functions during extrusion. First, moisture functions as a plasticizer to soften the dough and achieve certain rheological characteristics. Second, moisture is needed to achieve starch gelatinization and protein denaturation. Third,

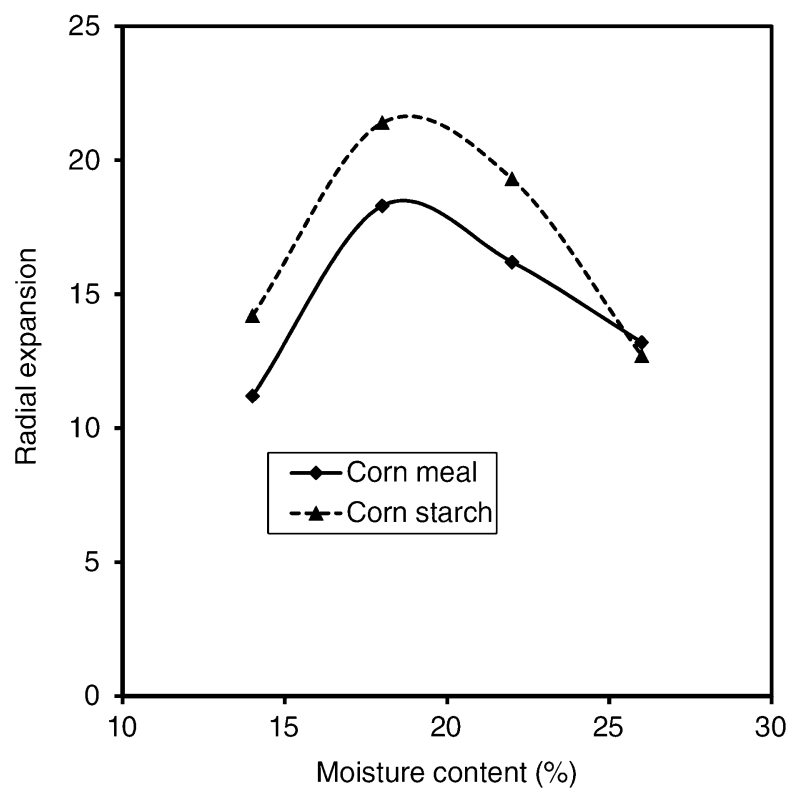

Figure 4. Relationship between moisture content and extrudate expansion. moisture acts as a lubricant within the barrel. Moisture reduces friction, lowering mechanical power input. Finally, moisture is used as a blowing agent in expanded food extrusions. The effect of moisture on expansion is twofold (Figure 4). At lower moisture contents, expansion increases as the moisture increases. There is a maximum expansion at optimum moisture content. Above that, expansion actually decreases as more moisture is added due to collapse of cells.

\section{Barrel Temperature}

Temperature is an indication of the thermal energy input to the system. For the raw materials to be fully cooked, both heat and moisture are needed. Generally, increasing temperature has a positive effect on the characteristics of the extruded products, such as degree of starch gelatinization and extrudate expansion. However, product color is affected negatively by barrel temperature.Higher temperature results in darker product color.

\section{Screw Rotational Speed}

Screw rotational speed determines the shearing action acting upon the dough, which in turn affects the heat dissipation from the mechanical energy input. Higher screw speeds introduce greater shear action. Screw speed also influences the residence time of the dough. Slower screw speed results in a longer residence time, which is sometimes critical for the completion of texture formation and chemical reactions.

\section{Screw Configuration}

Screw configuration refers to the selection of screw elements to achieve the desired processing conditions. As most of the commercial extruders use segmented screws, unlimited numbers of screw configurations can be achieved. Selection of a screw configuration depends mostly on past experience. For example, one can use double-flighted elements to speed up movement of materials, kneading blocks to increase mixing action on the dough, and reverse pitched elements to increase retention time. 


\section{Feed Rate}

Feed rate has an overall effect on extrusion. Feed rate affects the residence time, torque load, barrel pressure, and dough temperature. Generally, an extruder is operated at the maximum feed rate to achieve maximum output. However, starve feeding is sometimes employed to increase the residence time and achieve the desired extrudate characteristics.

\section{DRYING OPERATIONS}

Some freshly extruded products have moisture contents that are too high for safe storage. The excessive moisture needs to be removed by a drying operation. Drying operations for semimoist extruded products are carried out mostly on fluidized bed dryers. This type of dryer is operated continuously with high heat and mass transfer efficiencies and is self-cleaning.

\section{EXTRUSION MODELING AND AUTOMATIC CONTROL}

As extrusion involves multiple variables as mentioned above, it is difficult for an extruder operator to manually adjust all the variables to the optimum levels. Therefore, it is desirable to apply automatic controls to an extrusion system. Automation means that the operating parameters are controlled and regulated to operate at the preset values by a control system.[5] Extrusion automation improves product quality, maximizes extruder throughput, and saves operating costs. An automated extruder can have a programmable panel or a computer system, sensors, and relays.

In order to apply an automation technique to an extrusion system, a basic understanding of the extrusion process is essential. In order to eliminate the depen- dency of a process model on a special machine, secondary or process variables are developed, including dough viscosity, residence time, and energy input. Product characteristics are correlated directly with the abovementioned process variables and not with the operating variables. The models should not be machine-dependent. With the development of computer technology, new methods of modeling, neural network, and fuzzy logic have been employed to model the extrusion process. Compared to the more traditional mathematical and statistical models, neural network and fuzzy logic models have the advantages of handling multiple variables, predicting more accurately, and being implemented more easily.

ACKNOWLEDGMENT - The contributions of Dr. Yubin Lan, USDA-ARS, College Station, Texas, to an earlier edition of this entry are acknowledged.

\section{REFERENCES}

1. Meuser, F.; Wiedmann, W. Extrusion plant design. In Extrusion Cooking; Mercier, C., Linco, P., Harper, J., Eds.; American Association of Cereal Chemists: St. Paul, MN, 1989.

2. Rokey, G.J. Single screw extruder. In Extruders in Food Applications; Riaz, M.N., Ed; Technomic Publishing Co.: Lancaster, PA, 2000; 30-31.

3. Linko, P.; Colonna, P.; Mercier, C. High temperature short time extrusion. In Advances in Cereal Science and Technology; Pomeranz, Y., Ed.; American Association of Cereal Chemists: St. Paul, MN, 1981; 145-235.

4. Starer, M.S. When to consider a twin screw extruder for making pet food and the use of high speed. In Advances in Extrusion Technology; Chang, Y.K., Wang, S.S., Eds.; Technomic Publishing Co., Inc.: Lancaster, PA, 1998.

5. Millauer, C. The monitoring and control of an extrusion system. In Extrusion Technology for the Food Industry; O'Connor, C., Ed.; Elsevier Applied Science Publishers: London, 1987; 54-70. 